\title{
Research on the Reformation of College Physical Education
}

\author{
X.P. MA, C.H. JIANG \\ School of sports economy and management, Central University of Finance and Economics, Beijing, China
}

F. LIANG

Company of Postgraduate Management, the Academy of Equipment, Beijing 101416, China

\begin{abstract}
Nowadays, with the rapid development of college cultivation, the college physical education has been pay more attention by the government. The reformation of college physical education can benefit the development of physical education as well as conducive the quality education implementation. The main aim of the reformation is to enhance students' physique. In this paper, we analyze the physical education impact in the college cultivation system. Some conclusions and suggestions of the reform in college physical education are proposed in this paper.
\end{abstract}

KEYWORD: Physical education; College; Reformation

\section{INTRODUCTION}

Direction of the reform of college physical education should be to stress in a based on the premise of students' physical quality, training and development of the students' interest in sports and special skills. College sports education to guide students through the physical exercise to overcome the psychological, physical, physical weakness [1]. Nowadays, the college physical education from both theory and practice has carried on the positive exploration and bold reform, which made greater progress than before in many ways. However, the reforms relative to the sports concept of the new century is not enough comprehensive and incomplete and many problems still exist [2-5].

Firstly, many colleges and universities still outstanding teachers as the center, to get them to release their own personality, ignoring the improvement of students' physical quality, and to some extent hindered the process of the reform of college sports. On the other hand, the college sports is equipped with no use of software and hardware, and the lack of qualified teachers, narrow money spent, equipment resources nervous. All the problems mentioned above make it clearly that the reformation of the college physical education is necessary. In this paper, we first introduce the concept of physical education reform and its positive role in the college cultivation. Subsequently, some development problems in our country's college physical education have been analyzed, finally gives some suggestions to solve these problem.
The rest of the paper is organized in the following sequence. In Section 2, the college physical education reform is introduced in detail. In Section 3 , some suggestions for the college physical education reform in our country will be proposed. Concluding remarks are summarized in the final section.

\section{THE REFORM OF COLLEGE PHYSICAL EDUCATION}

With the development of college sports is the political, economic and cultural development of the whole society is closely related, its reform is advancing with the ages. College physical education can develop the students' body and mind, improve the level of students' quality, cultivating a new constitution of talents. In terms of the situation, the reasonable choice of teaching content, scientific arrangement of physical and mental exercise load, USES has the reform of the new organization law, is still in line with the basic situation of our country's colleges and universities sports teaching [6].

The college physical education should be based on different grade students' physical and mental characteristics, the effective development of students' physical quality, basic activities to improve students ability, is good for carrying forward the culture of sports stimulate students sense of competition and satisfy the interest in sport as the content of the textbook [6]. Nowadays, the colleges set up a variety of different conditions according to 
their own individual association of sports and fitness club, some of which have been gradually converted from "welfare" to "consumption". Moreover, more and more students use weekend open sports venues, fitness recreation activities, there are also put forward the idea of opening the campus sports culture market. However, most colleges and universities sports facilities is not enough to meet the needs of individual sports consumption currently. Therefore, how to adjust measures to local conditions, organized in a planned way to arrange all kinds of small variety of mass sports activities, is a one of the focus of college physical education reform.

College sports cultivation as an important part of college education, to carry the cultivating students' ability, innovation ability and shape the students the task of good character. Quality education must not be no sports, sports not only is the important content of quality education, but also an important means of quality education [7]. Nowadays, our country calls for the students who have all-round development. Hence, college physical education curriculum in education as the highest goal, the state and the social requirements for college students' sports combined with the individual sports college students, the exercise and cultivate college students' lifelong sports consciousness, interest, habit and ability together. Physical education in colleges and universities should combine heart of sports and education, moral education and promote the allround development of college students' comprehensive quality, cultivate their abilities in the future of the society. Physical education in colleges and universities should promote the all-round development of college students' comprehensive quality, cultivate their abilities in the future of the society.

Of course, our government constantly increased the investment in college physical since 1978. However, the proportion of physical education funds stay in low level accounted to the college education total funding obviously according to the survey made by Jianjia Chen [8]. The proportion of college physical education funds in some college are showed in Table1 [10].

Table 1. The funds proportion in some investigated colleges.

\begin{tabular}{|c|c|c|}
\hline $\begin{array}{c}\text { Proportion of } \\
\text { funds }\end{array}$ & $\begin{array}{c}\text { Unmber of colleges } \\
(43)\end{array}$ & $\begin{array}{c}\text { Proportion of } \\
\text { colleges }\end{array}$ \\
\hline $0.2 \%$ & 8 & $18.6 \%$ \\
\hline $0.3 \%$ & 8 & $18.6 \%$ \\
\hline $0.4 \%$ & 8 & $18.6 \%$ \\
\hline $0.5 \%$ & 9 & $20.93 \%$ \\
\hline $0.5 \% \sim 1 \%$ & 8 & $18.6 \%$ \\
\hline More than $1 \%$ & 2 & $4.65 \%$ \\
\hline
\end{tabular}

* Column dialog box in Format menu.

\section{THE SUGGESTION FOR COLLEGE PHYSICAL EDUCATION REFORM}

The development of college physical education in our country becomes to animate since 1990s. The reform and opening-up policy makes the physical cultivation in Chinese colleges began to recover. It is right time to make some contribution for college physical education reform in our country. As can be seen from Table 1, the college physical education investment funds is relatively small, which seriously affected the healthy development of sports education in colleges and universities and it is not conducive to physical education reform. To promote the reformation of the college physical education in our country, some suggestions and suggested policies are proposed as follow:

\subsection{Use humanist education to strengthen college students in college sports}

College students in the university stage is not only to complete the accumulation of knowledge, more important is to complete the character and behavior of ability the shape. Therefore, we must reform the traditional teaching mode, and play the enthusiasm of students learning, give full play to student's learning potential.

\subsection{We should set up strong ideas of quality education}

On the education object to firmly establish a thought for the student's physical quality is given priority to, at the same time to promote the development of other quality comprehensive educational concept. On the choice of teaching contents, teaching methods, to establish take the student as the main body, promote students' personalized development concept.

\subsection{Introducing excellent athletes coaching team}

College PE teachers' own quality high and low, is the key to the implementation of quality education. Let the famous athletes in the form of a substitute to join the university sports teaching, both to alleviate the lack of college PE teachers, and to avoid the waste of national sports.

\subsection{Build strong campus sports culture atmosphere}

The propaganda to increase the university sports work. In various sports associations and clubs, give full play to their role, support them in their spare time and leisure holiday within organizations to carry out various forms, rich and colorful fitness, competitions, performances and other activities. 


\section{CONCLUSION}

With the rapid development of our country, the college physical education reform is becoming more and more important in the national development. Along with the advance of reform and opening up, the sports as an important part of social construction, is also affected. With the development of college sports is the development of the entire social politics, economy and culture are closely related. In this paper, we analyze the reform of physical education in our country. The importance of college physical education have been deeply researched. Finally, some suggestions and suggested policies are proposed in this paper.

\section{REFERENCES}

[1] Jiang C H, Liang F. Research on the Sports Economy Effection in National Economic Development//Applied
Mechanics and Materials. 2014, 556: 6519-6521.

[2] Zhao J. Theory of our country sports present situation and existing problems of economic development. Value Engineering. 2011, 21: 140.

[3] Bailey R. Evaluating the relationship between physical education, sport and social inclusion. Educational review, 2005, 57(1): 71-90.

[4] HONG P, ZHANG R, DING X. The Humanistic View on the Strategy of College Sports Teachers to Sports Education Reform. Journal of Nanjing Institute of Physical Education (Social Science), 2008, 4: 022.

[5] Zhang L W. Research methods of the sports science, Beijing, Higher Education Press, 2004.

[6] Zonghu Q. the Development and Concept of Physical Education Reform in Universities and Colleges in China. Sport Science, 1998, 4: 001.

[7] Zhang J, Long M. College PE reform and education for allround development. Journal-Wuhan Institute of Physical Education, 2004, 38: 130-131.

[8] Chen J J. Research on college sports present situation and countermeasure. Sichuan sports science, 1998, 2: 5-6. 